\title{
Immunogenetic heterogeneity of seronegative rheumatoid arthritis and the antiperinuclear factor
}

\author{
A M Th Boerbooms, A A A Westgeest, P Reekers, L B A van de Putte
}

\begin{abstract}
HLA typing was carried out in 132 patients with rheumatoid arthritis (RA) with long term follow up, and special attention was focused on rheumatoid factor negative patients. The patients were divided into four groups: 55 patients with a seropositive $R A$ and a positive antiperinuclear factor (group A); 39 seropositive patients but a negative antiperinuclear factor (group B); 14 patients consistently seronegative for 3-28 years (mean 11.8 years) but positive for antiperinuclear factor (group C); patients consistently negative for 3-28 years (mean 11.8) and also negative for antiperinuclear factor (group D). The prevalence of HLA-DR4 was 31/55 (56\%), 29/39 (74\%), 10/14 (71\%), and 9/24 (37\%) for groups A, B, C, and $D$ respectively, and in all groups was significantly higher than in $\mathbf{2 7 7}$ healthy controls (55/ $277,20 \%$ ). No significant difference was found between seropositive (groups $A$ and B) and seronegative (groups $C$ and $D$ ) patients, but groups A, B, and C had higher prevalences than group $D$. It is concluded that in seronegative RA HLA-DR4 is preferentially associated with the antiperinuclear factor positive group.
\end{abstract}

Although an association between HLA-DR4 and adult onset rheumatoid arthritis (RA) has been firmly established, ${ }^{1-9}$ it is uncertain whether the same DR4 association exists in subgroups of patients with RA. ${ }^{2} 5^{10-13}$ Rheumatoid factor negative patients with RA diagnosed according to the American Rheumatism Association criteria ${ }^{14}$ form a clinical subgroup that can be subdivided into antiperinuclear factor positive (RF- APF+) and antiperinuclear factor negative (RF- APF-) patients. The antiperinuclear factor is highly specific for RA, but its sensitivity is rather low. ${ }^{15-17} \mathrm{We}$ recently showed that in seronegative RA the presence of antiperinuclear factor is related to a more severe form of the disease. ${ }^{18}$ In this study we investigated the HLA association in four subgroups of patients with RA, differing in rheumatoid factor and antiperinuclear factor positivity and negativity.

\section{Patients and methods} PATIENTS

A cohort of 132 outpatients ( 96 female, 36 male) with $\mathrm{RA}^{14}$ and with a disease duration of at least three years was studied. More details of these patients have been given previously. ${ }^{18}$ Patients were classified in four groups according to the presence or absence of rheumatoid factor and antiperinuclear factor. Group A patients were positive for both antibodies (RF+ APF+); group B were rheumatoid factor positive and antiperinuclear factor negative ( $\mathrm{RF}+\mathrm{APF}-)$; group $C$ consisted of rheumatoid factor negative and antiperinuclear factor positive patients (RF-APF+); and group D patients negative for both antibodies ( $R F-A P F-)$.

Rheumatoid factor and the antiperinuclear factor were determined at least three times during the course of the disease, with a minimum interval of at least one year. Patients were examined to exclude other rheumatic diseases (systemic lupus erythematosus, psoriatic arthritis, degenerative joint disease, seronegative spondyloarthropathy). In most rheumatoid factor negative patients (34/38) radiological examination of the pelvis or sacroiliac joints was also performed to exclude sacroiliitis.

All antibody determinations used to classify patients were performed before they were treated with slow acting antirheumatic drugs.

\section{RHEUMATOID FACTOR DETERMINATION}

The presence of IgM rheumatoid factor was detected by the Waaler-Rose test and the latex fixation test. These agglutination assays were performed as a microtitre modification ${ }^{19}$ of the technique described earlier. ${ }^{20}$ All patients regarded as rheumatoid factor negative always had a Waaler-Rose test of $\leqslant 1 / 40$ and a latex fixation test of $\leqslant 1 / 32$ in all serum samples tested. Some patients had a Waaler-Rose test of $1 / 80$ or a latex fixation test of $1 / 64$ in only one serum sample, all other samples being negative; these patients were also classified as rheumatoid factor negative.

\section{ANTIPERINUCLEAR FACTOR}

\section{DETERMINATION}

The antiperinuclear factor assay has been described previously. ${ }^{15-18}$ In brief, human buccal mucosa cells were used as substrate. Antibodies against the granules around the nucleus of these cells were detected with a fluorescence technique. Fluorescence was scored in four categories according to Marmont et $a l,{ }^{16}$ ranging from 0 to +++ . Patients were classified as antiperinuclear factor positive when at least one serum sample during the course of the disease had antiperinuclear factor ++ or +++ or two different serum samples obtained with a least a one year interval had antiperinuclear factor + . Other patients were recorded as antiperinuclear factor negative. 
HLA TYPING

HLA typing was done with standard NIH microlymphocytotoxicity techniques for HLAB27 and DR antigens. DR typing was done twice with two different sets of reagents on enriched B lymphocyte suspensions obtained after rosetting with 2-aminoethylisothiouronium bromide treated sheep red blood cells. Serum samples were partly of local origin, all sera being standardised against the 9th and 10th International Histocompatibility Workshop sera.

A random group of 277 healthy unrelated white blood donors from the same area as the patients served as controls.

STATISTICAL ANALYSIS

Fisher's exact test and the $\chi^{2}$ test were used for comparison of proportions to assess the statistical significance of data. Means of disease duration were tested with the $t$ test for comparison of two independent means. p Values of 0.05 or less were regarded as significant.

\section{Results}

Table 1 summarises the principal clinical data. Thirty eight of the 132 patients (groups $C+D$ ) were negative for rheumatoid factor $(29 \%)$, of whom 24 were antiperinuclear factor negative $(63 \%)$ and 14 antiperinuclear factor positive $(37 \%)$. The mean disease duration was longer in the seropositive subgroups $(\mathrm{RF}+\mathrm{APF}+; \mathrm{RF}+$ APF-) than in the seronegative subgroups (RF- APF + ; RF-APF-). Sex, age, and disease duration showed no statistically significant differences between the four groups. Patients in the seropositive subgroups more commonly had subcutaneous nodules than those in the seronegative subgroups. In the seronegative group prevalence of nodules was slightly higher in the RF - APF + group than in the RF-APF-group ( $29 \% v 17 \%)$.
The prevalence of HLA-DR4 was significantly greater in all four RA groups than in the healthy controls (table 2). When rheumatoid factor positive patients (groups $\mathrm{A}+\mathrm{B}$ ) were compared with rheumatoid factor negative patients (groups $\mathrm{C}+\mathrm{D}$ ) no difference in DR4 positivity was seen $\left(p=0 \cdot 13 ; \chi^{2}=2 \cdot 09\right)$. The patients in group $C$ had a significantly $(p<0.04)$ greater HLA-DR4 prevalence $(71 \%)$ than the patients in group $\mathrm{D}(37 \%)$. The patients positive for rheumatoid factor or antiperinuclear factor, or both (groups A, B, or C) had a greater DR4 prevalence than the seronegative group without antiperinuclear factor (group D), but the difference was not significant for group A compared with group $\mathrm{D}\left(\mathrm{p}<0.07 ; \chi^{2}=3.46\right)$. The prevalences of the other HLA-DR antigens in the seronegative subgroups $(\mathrm{RF}-\mathrm{APF}+v$ $\mathrm{RF}$ - APF-) were not significantly different; the B27 prevalence was normal in all subgroups.

\section{Discussion}

In this study of patients with RA an increased prevalence of HLA-DR4 was seen in those positive for rheumatoid factor with or without antiperinuclear factor and those negative for rheumatoid factor but positive for antiperinuclear factor compared with patients negative for both antibodies. We recently reported that the presence of antiperinuclear factor in seronegative RA is an indication of more severe disease. ${ }^{18}$ The immunogenetic heterogeneity in seronegative RA with and without antiperinuclear factor perhaps indicates that there is an immunogenetic basis for the difference in severity of disease. There are conflicting opinions about the relation between rheumatoid factor negative RA and HLA-DR4. ${ }^{2}{ }^{10-13}$ Some authors describe a normal prevalence of HLA-DR4 in seronegative $\mathrm{RA}^{2}{ }^{3}$ and a significantly increased prevalence in seropositive RA. ${ }^{1-9}$

On the other hand, other studies concluded

Table 1: Principal clinical data of the 132 patients with rheumatoid arthritis studied

\begin{tabular}{|c|c|c|c|c|}
\hline & $\begin{array}{l}\text { Group } A \\
R F+A P F+t \\
(n=55)\end{array}$ & $\begin{array}{l}\text { Group B } \\
R F+A P F- \\
(n=39)\end{array}$ & $\begin{array}{l}\text { Group } C \\
R F-A P F+ \\
(n=14)\end{array}$ & $\begin{array}{l}\text { Group D } \\
R F-A P F- \\
(n=24)\end{array}$ \\
\hline $\begin{array}{l}\text { Sex (female/male) } \\
\text { Age (years) }\end{array}$ & $2 \cdot 2$ & 3.9 & $2 \cdot 5$ & $2 \cdot 4$ \\
\hline $\begin{array}{l}\text { Mean } \\
\text { Range } \\
\text { Disease duration (years) }\end{array}$ & $\begin{array}{l}56 \\
36-82\end{array}$ & $\begin{array}{l}56 \\
35-80\end{array}$ & $\begin{array}{l}51 \\
28-69\end{array}$ & $\begin{array}{l}51 \\
29-83\end{array}$ \\
\hline $\begin{array}{l}\text { Mean } \\
\text { Range } \\
\text { Subcutaneous nodules (\%) }\end{array}$ & $\begin{array}{l}14 \cdot 7 \\
4-32 \\
60\end{array}$ & $\begin{array}{l}15 \cdot 8 \\
3-32 \\
41\end{array}$ & $\begin{array}{l}11 \cdot 8 \\
3-28 \\
29^{*}\end{array}$ & $\begin{array}{l}11 \cdot 8 \\
3-28 \\
17^{*}\end{array}$ \\
\hline
\end{tabular}

${ }^{*} \mathrm{p}=0.01$ for $\mathrm{RF}-\mathrm{APF}+$ and $\mathrm{RF}-\mathrm{APF}-v \mathrm{RF}+\mathrm{APF}+$

$+\mathrm{RF}=$ rheumatoid factor; $\mathrm{APF}=$ antiperinuclear factor.

Table 2: Prevalence of HLA-DR4 in patients with rheumatoid arthritis, differing in rheumatoid factor and antiperinuclear factor positivity and negativity, and in healthy controls

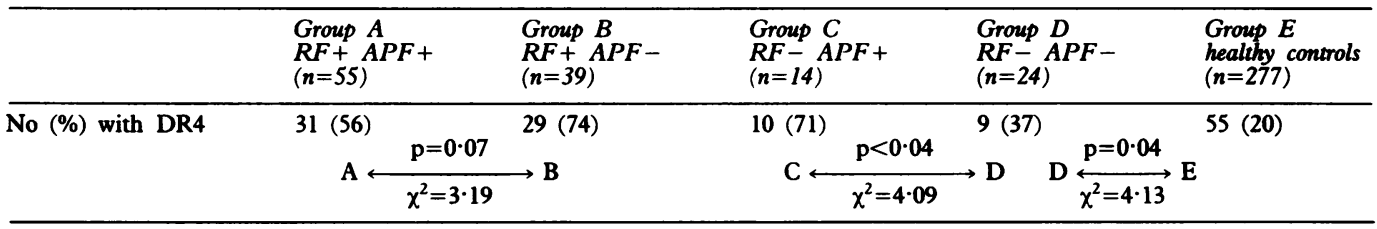

${ }^{*} \mathrm{RF}=$ rheumatoid factor; $\mathrm{APF}=$ antiperinuclear factor. 
that the presence of HLA-DR4 is the same in seropositive and seronegative $R A,-8 \quad 2122$ as also found in our study. An important point of discussion is the diagnosis seronegative RA. ${ }^{10}$ Our seronegative patients were followed up for 3-31 years (mean 11.8 ) and during the follow up the diagnosis remained unchanged and the rheumatoid factor was consistently negative. Seronegative spondyloarthropathy was unlikely to be present because there were no clinical signs of the disease; also the prevalence of HLA-B27 in the four patient groups was the same as that in the control group, and the radiological changes in hands, wrists, and feet were those observed in patients with RA. In addition, in 34 of the 38 rheumatoid factor negative patients radiographs of the pelvis or sacroiliac joints, or both, were made. Only one patient had a possible sacroiliitis. That patient was negative for HLA-B27 and had erosive lesions in hands and feet.

As far as we are aware this is the first report of an HLA study in patients with RA in which a significant difference in the prevalence of HLADR4 in subgroups of seronegative RA has been described. In these patients the prevalence of HLA-DR4 in the seronegative group with antiperinuclear factor was the same as that in the seropositive group. The seronegative patients with RA without antiperinuclear factor had a significantly lower prevalence than the seronegative patients with antiperinuclear factor.

The authors thank Mrs Marion Janssen for her excellent secretarial help. This work was supported by a grant from the Dutch League against Rheumatism.

1 Stastny P. Association of the B cell alloantigen DRw4 with rheumatoid arthritis. N Engl f Med 1978; 298: 869-71.

2 Doblong J H, Forre O, Käss E, Thorsby E. HLA antigens and rhe

3 Alarcon G S, Koopman W J, Acton R T, Barger B O.
Seronegative rheumatoid arthritis. A distinct immunogenetic disease? Arthritis Rheum 1982; 25: 502-7.

4 Terkeltaub R, Decary F, Esdaile J. An immunogenetic study of older age onset rheumatoid arthritis. $\mathcal{F}$ Rheumatol 1984; 11: 147-52.

5 Walton K, Dryer P A, Grennan B H, Haeny M, Harris R. Clinical features, auto-antibodies and HLA-DR antigens in rheumatoid arthritis. I Rheumatol 1985; 12: 223-6.

6 Thomsen M, Morling N, Snorrason E, Svejgaard A Sorenson S F. HLA-Dw4 and rheumatoid arthritis. Tissue Antigens 1979; 13: 56-60.

7 Scherak O, Smolen J S, Mayr W R. Rheumatoid arthritis and B lymphocyte alloantigen HLA-DRw4. F Rheumatol 1980; 7: 9-12.

8 Panayi G S, Wooley P, Batchelor J R. Genetic basis of rheumatoid disease: HLA antigens, disease manifestation and toxic reactions to drugs. $\mathrm{Br} M e d \mathcal{F} 1978$; ii: 1326-8.

9 Jaraquemada D, Ollier W, Awad J, et al. HLA and rheumatoid arthritis: a combined analysis of 440 British patients. Ann Rheum Dis 1986; 45: 627-36.

10 Calin A, Marks S H. The case against seronegative rheumatoid arthritis. Am F Med 1981; 70: 992-4.

11 Gran J T, Husby G. Seronegative rheumatoid arthritis and HLA-DR4. Proposal for criteria. $\mathcal{F}$ Rheumatol 1987; 14: 1074-82.

12 Masi A T. Rheumatoid factor negative (seronegative) rheumatoid arthritis. Evolving clinical classification and immunogenetic associations. F Rheumatol 1988; 15: 4-6.

13 Woodrow J C. Immunogenetics in rheumatoid arthritis. f Rheumatol 1988; 15: 1-3.

14 Arnett F C, Edworthy S M, Bloch D A, et al. The American Rheumatism Association 1987 revised criteria for the classification of rheumatoid arthritis. Arthritis Rheum 1988; 31 : 315-24.

15 Nienhuis R L F, Mandema E. A new serum factor in patients with rheumatoid arthritis. The antiperinuclear factor. Ann wheum Dis 1964; 23: 302-5.

16 Marmont A M, Damasio E E, Bertorello C, Rossi F. Studies on the antiperinuclear factor. Arthritis Rheum 1967; 10: on the anti $117-28$.

17 Sondag-Tschroots J R J M, Aaij C, Smit J W, Feltkamp T E W. The antiperinuclear factor. I. The diagnostic significance of the antiperinuclear factor for rheumatoid arthritis. Ann Rheum Dis 1979; 38: 248-51.

18 Westgeest A A A, Boerbooms A M Th, Jongmans $M$ VandenBroecke J P, Vierwinden G, van de Putte L B A Antiperinuclear factor: indicator of more severe disease seronegative rheumatoid arthritis. $\mathcal{f}$ Rheumatol 1987; 14: 893-7.

19 Klein F, Bronsveld W, Norde W. A modified latex fixation test for the detection of rheumatoid factors. $\mathcal{F}$ Clin Pathol test for the detecti
$1979 ; 32: 90-2$.

20 Singer J M, Plotz C M. The latex fixation test. I. Application to the serologic diagnosis of rheumatoid arthritis. Am $\mathcal{f}$ Med 1956; 21: 888-92.

21 Panayi G S, Celinska E, Emersj P, et al. Seronegative and seropositive rheumatoid arthritis: similar diseases. $\mathrm{Br} \mathcal{F}$ Rheumatol 1987; 26: 172-80.

22 Gran J T, Husby G, Thorsby E. The association between rheumatoid arthritis and the HLA antigen DR4. Ann Rherm Dis 1983; 42: 292-6. 